\title{
Induksi Tetraploid Tunas Pucuk Jeruk Siam Simadu (Citrus nobilis Lour) Menggunakan Kolkisin secara In Vitro
}

\author{
In Vitro Induction of Tetraploid in Simadu Tangerine \\ (Citrus nobilis Lour) Shoot-Tip Using Colchicine
}

\author{
Fitri Yulianti' ${ }^{*}$, Agus Purwito $^{2}$, Ali Husni ${ }^{3}$, dan Diny Dinarti² \\ ${ }^{1}$ Program Studi Pemuliaan dan Bioteknologi Tanaman, Sekolah Pascasarjana, Institut Pertanian Bogor \\ ${ }^{2}$ Departemen Agronomi dan Hortikultura, Fakultas Pertanian, Institut Pertanian Bogor \\ (Bogor Agricultural University), Jl. Meranti, Kampus IPB, Darmaga, Bogor 16680, Indonesia \\ ${ }^{3}$ Balai Besar Penelitian dan Pengembangan Bioteknologi dan Sumberdaya Genetik Pertanian, \\ J1. Tentara Pelajar 3A Bogor 16111, Indonesia
}

Diterima 21 Maret 2014/Disetujui 10 September 2014

\begin{abstract}
Seedless fruit is one of the criteria (necessary) to improve the quality of Simadu tangerine. The most effective method to obtain seedless triploid cultivars is hybridisation between tetraploid and diploid parents. Simadu tangerine is a diploid plant. Tetraploid Simadu tangerine can be obtained with doubling chromosome using colchicines. The aim of this research was to obtain tetraploid Simadu tangerine shoot which would serve as parent to produced seedless Simadu tangerine. Shoottips of Simadu tangerine without leaves were treated with colchicines at four different concentrations (0, 0.1, 0.2, and 0.3\%) for 3 hours. The results showed that the high concentration of $0.3 \%$ reduced survival rate. The colchicine treatments reduced growth of shoot-tip of Simadu Tangerine.The leaves of colchicines treated shoots were thicker than control. Leaves from control ( $0 \%$ colchicine) and $0.1 \%$ colchicine treated shoots had 8.67 and 18.25 chloroplast per pair of guard cells. Compared to those of control, leaves with $0.1 \%$ colchicine had lower stomatal density, and larger stomatal size. It appeared that $0.1 \%$ colchicine treatment resulted in tetraploid Simadu Tangerine Shoot.
\end{abstract}

Keywords:chloroplasts, doubling chromosomes, stomatal size, stomatal density

\section{ABSTRAK}

Buah seedless merupakan salah satu kriteria untuk dapat meningkatkan kualitas jeruk Siam Simadu.Metode yang paling efektif untuk mendapatkan jeruk Siam Simadu seedless adalah dengan cara menyilangkan antara tetua tetraploid dan diploid. Jeruk Siam Simadu merupakan tanaman diploid. Tanaman jeruk Siam Simadu tetraploid dapat diperoleh melalui penggandaan kromosom menggunakan kolkisin. Tujuan penelitian ini adalah mendapatkan tunas tetraploid jeruk Siam Simadu yang dapat digunakan sebagai tetua untuk menghasilkan jeruk Siam Simadu tanpa biji. Tunas pucuk jeruk Siam Simadu tanpa daun direndam dalam larutan kolkisin selama 3 jam dengan konsentrasi 0, 0.1, 0.2, dan 0.3\%. Hasil penelitian menunjukkan bahwa konsentrasi kolkisin yang tinggi $0.3 \%$ mengurangi jumlah tunas yang hidup. Perlakuan kolkisin menurunkan pertumbuhan tunas pucuk jeruk Siam Simadu. Daun tunas pucuk yang diberikan perlakuan kolkisin lebih tebal dibandingkan dengan daun tunas pucuk kontrol. Daun dari tunas kontrol (0\% kolkisin) dan perlakuan kolkisin $0.1 \%$ memiliki 8.67 dan 18.25 kloroplas per pasang sel penjaga. Daun tunas perlakuan kolkisin 0.1\% memiliki kerapatan stomata yang lebih rendah dan ukuran stomata yang lebih besar dibandingkan dengan daun tunas kontrol. Perlakuan kolkisin $0.1 \%$ menghasilkan tunas tetraploid jeruk Siam Simadu.

Kata kunci: kloroplas, penggandaan kromosom, ukuran stomata, kerapatan stomata

\section{PENDAHULUAN}

Jeruk merupakan komoditas buah yang paling banyak diimpor di Indonesia. Berdasarkan data dari Direktorat

\footnotetext{
* Penulis untuk korespondensi. e-mail: fitri_yulianti88@yahoo. com
}

Jenderal Hortikultura (2013) nilai impor jeruk Indonesia mencapai US \$227,300,473. Jeruk impor lebih diminati konsumen karena memiliki kriteria yaitu warna yang menarik, kulitnya mudah dikupas, rasanya segar dan hampir tidak mempunyai biji (seedless). Jeruk Siam Simadu merupakan jeruk Siam lokal yang hampir mendekati kategori tipe jeruk yang sesuai dengan kriteria konsumen dan pasar dunia untuk dikonsumsi dalam keadaan segar 
tetapi mempunyai biji yang relatif banyak yaitu lebih dari 15 biji per buah sehingga kalah bersaing dengan jeruk impor (Husni et al., 2010).

Perbaikan kualitas jeruk lokal yang sudah memiliki rasa dan warna yang sesuai dengan kriteria konsumen dan pasar dapat dilakukan dengan merakit tanaman jeruk lokal tersebut memiliki buah jeruk seedless. Jeruk Siam (Citrus nobilis Lour) termasuk dalam kelompok jeruk dengan jumlah kromosom $2 \mathrm{n}=2 \mathrm{x}=18$. Menurut $\mathrm{Wu}$ dan Mooney (2002), metode yang paling efektif untuk mendapatkan tanaman jeruk tanpa biji atau triploid $(2 n=3 x=27)$ yaitu dengan cara menyilangkan tanaman jeruk tetraploid $(2 n=4 x=36)$ dengan tanaman jeruk diploid $(2 \mathrm{n}=2 \mathrm{x}=18)$.

Tanaman jeruk tetraploid dapat dihasilkan dengan perlakuan kolkisin. Menurut Takahira et al. (2011), kolkisin dapat digunakan untuk menggandakan jumlah kromosom. Ascough et al. (2008) mengemukakan bahwa kolkisin dapat menghambat pembentukan dan aktivitas benang-benang spindle pada saat pembelahan sel mitosis serta mencegah inti dan sel membelah sehingga jumlah kromosom sel mengganda. Menurut Dhooghe et al. (2011), penggandaan jumlah kromosom menggunakan kolkisin sangat tergantung pada konsentrasi kolkisin yang diberikan.

Gmitter danLing (1991) berhasilmendapatkan tanaman jeruk tetraploid Orlando Tangelo dengan menggunakan perlakuan kolkisin $0.1 \%$. Berdasarkan penelitian Zeng et al. (2006), perlakuan kolkisin $0.1 \%$ dapat menghasilkan tanaman jeruk tetraploid Frost (Citrus sinensis Osbeck). Aleza et al. (2009) dapat memperoleh tanaman jeruk tetraploid varietas Clemenules dengan pemberian kolkisin $0.1 \%$. Penelitian ini bertujuan untuk mendapatkan tunas jeruk Siam Simadu tetraploid yang akan dijadikan sebagai tetua untuk menghasilkan jeruk Siam Simadu seedless.

\section{BAHAN DAN METODE}

Kegiatan penelitian dilaksanakan dari bulan Januari 2013 sampai dengan Agustus 2013. Tempat pelaksanaan penelitian in vitro dilakukan di Laboratorium Kultur Jaringan Kelompok Peneliti Biologi Sel dan Jaringan, Balai Besar Penelitian dan Pengembangan Bioteknologi dan Sumberdaya Genetik Pertanian (BB-BIOGEN), Cimanggu, Bogor. Uji sitologi dilakukan di Laboratorium Micro Technique, Departemen Agronomi dan Hortikultura, Fakultas Pertanian, Institut Pertanian Bogor.

Bahan tanaman yang digunakan adalah tunas pucuk in vitro jeruk Siam Simadu. Media recovery (pemulihan) yang dipakai adalah media dasar Murashige-Skoog (MS) yang dimodifikasi dengan vitamin Morel and Wetmore (MW) dan ditambahkan ekstrak malt (EME) $0.5 \mathrm{~g} \mathrm{~L}^{-1}$. Media pertumbuhan yang digunakan adalah media dasar MS yang dimodifikasi dengan vitamin MW (Tabel 1). Bahan pengganda kromosom yang digunakan kolkisin $\mathrm{C}_{22} \mathrm{H}_{25} \mathrm{O}_{6} \mathrm{~N}$ (SIGMA).

Rancangan percobaan yang digunakan adalah Rancangan Kelompok Lengkap Teracak (RKLT) satu faktor yaitu konsentrasi kolkisin. Konsentrasi kolkisin yang diberikan yaitu $0,0.1,0.2$ dan $0.3 \%$. Setiap perlakuan diulang sebanyak lima kali, satu ulangan terdiri atas dua tunas pucuk jeruk yang ditanam dalam satu botol.

Pembuatan larutan kolkisin dilakukan dengan cara menimbang kolkisin sesuai dengan konsentrasi perlakuan menggunakan timbangan analitik, kemudian dilarutkan ke dalam aquades steril. Larutan tersebut diukur $\mathrm{pH}$ hingga 5.6 menggunakan $\mathrm{pH}$ meter. Sterilisasi larutan kolkisin menggunakan milipore $0.20 \mu \mathrm{m}$ di dalam laminar air flow cabinet (LAFC).

Pembuatan media dilakukan dengan cara mencampurkan media dasar MS dengan vitamin MW pada erlenmeyer dan EME $0.5 \mathrm{~g} \mathrm{~L}^{-1}$, lalu ditambahkan gula pasir sebanyak $30 \mathrm{~g} \mathrm{~L}^{-1}$ dan diaduk menggunakan magnetic stirer hingga larut. Aquades ditambahkan sampai volume campuran larutan tersebut mencapai hampir $1 \mathrm{~L}$. Campuran larutan tersebut diukur $\mathrm{pH}$ hingga 5.8, lalu ditera dengan menggunakan labu ukur dan ditambahkan $2.5 \mathrm{~g} \mathrm{~L}^{-1}$ phytagel sebagai pemadat. Campuran larutan stok dimasak dan terus diaduk sampai mendidih menggunakan hot plate. Media campuran tersebut dimasukkan ke dalam botol-botol sebanyak $25 \mathrm{~mL}$ per botol lalu ditutup dengan alumunium foil. Alumunium foil penutup botol diberi kode, kemudian media disterilisasi dalam autoclave selama 15 menit pada suhu $121{ }^{\circ} \mathrm{C}$. Media yang telah disterilisasi disimpan di ruang media pada suhu $16^{\circ} \mathrm{C}$.

Induksi tetraploid tunas pucuk in vitro jeruk Siam Simadu dilakukan di dalam LAFC dengan cara memotong tunas pucuk jeruk Siam Simadu dari planlet dan membuang semua daun lalu direndam pada larutan perlakuan kolkisin yaitu $0,0.1,0.2$ dan $0.3 \%$ selama 3 jam sambil diguncangguncang dengan menggunakan shaker agar larutan kolkisin mengenai keseluruhan bagian tunas. Tunas yang telah diberi perlakuan kolkisin kemudian dibilas dengan aquades steril dan dikeringkan dengan kertas saring lalu ditanam pada media recovery (pemulihan) dan disimpan pada ruang kultur dengan penyinaran menggunakan lampu $20 \mathrm{~W}$ selama 16 jam hari $^{-1}$ dengan intensitas cahaya rata-rata 1,500-2,000 lux, dengan suhu $16-20{ }^{\circ} \mathrm{C}$ selama dua minggu kemudian disubkultur ke media pertumbuhan dan disimpan kembali ke ruang kultur.

Analisis stomata dilakukan pada daun teratas yang telah membuka sempurna dan memiliki ukuran yang cukup besar. Daun dipotong dan bagian epidermis daun diletakkan pada gelas arloji dan ditetesi aquades. Bagian

Tabel 1. Komposisi vitamin Morel and Wetmore (MW)

\begin{tabular}{lc}
\hline Vitamin & Bahan kimia $\left(\mathrm{mg} \mathrm{L}^{-1}\right)$ \\
\hline Calcium Panthotenat & 0.5 \\
Myoinositol & 100 \\
Nicotinic Acid & 1 \\
Pyridoxine $\mathrm{HCl}(\mathrm{B} 6)$ & 1 \\
Thiamine $\mathrm{HCl}(\mathrm{B} 1)$ & 1 \\
Biotine & 0.001 \\
\hline
\end{tabular}

Sumber: Morel dan Wetmore (1951) 
epidermis daun dikupas dengan hati-hati menggunakan silet sampai menghasilkan lapisan yang tipis. Lapisan tipis daun yang dihasilkan kemudian dibalik dan ditetesi aquades secukupnya lalu ditutup dengan cover glass. Sekeliling cover glass diberi cat kuku bening dan dikeringkan. Preparat diamati pada perbesaran $10 \times 100$ menggunakan mikroskop Olympus BX51 dan difoto. Pengamatan dilakukan pada lima bidang pandang yang dipilih secara acak dengan lima ulangan.

Pengamatan yang dilakukan adalah $\mathrm{LD}_{50}$ (lethal dose) yaitu dosis yang menyebabkan $50 \%$ kematian dari populasi yang dimutasi (Aisyah et al. 2009), tinggi tunas, jumlah buku, jumlah daun baru yang terbentuk, panjang akar, jumlah akar, tebal daun, jumlah kloroplas, kerapatan stomata, serta ukuran panjang dan lebar stomata pada sel penjaga.

Analisis data menggunakan uji F. Apabila hasil uji F berbeda nyata, maka dilakukan uji lanjut DMRT (Duncan's Multiple Range Test) pada taraf nyata 5\%. Penghitungan rata-rata dan standar deviasi kloroplas pada sel penjaga, kerapatan stomata, dan ukuran stomata menggunakan Microsoft Excel.

\section{HASIL DAN PEMBAHASAN}

Nilai $\mathrm{LD}_{50}$ dapat diperoleh dengan menghitung pola respon kematian tanaman terhadap berbagai konsentrasi kolkisin yang diberikan. Gambar 1 memperlihatkan bahwa semakin tinggi konsentrasi kolkisin, maka semakin tinggi persentase tunas pucuk jeruk yang mati. Pola respon kematian tunas pucuk jeruk terhadap berbagai konsentrasi kolkisin menghasilkan respon linear. Persamaaan respon kematian tunas pucuk jeruk terhadap berbagai konsentrasi kolkisin yaitu $\mathrm{y}=270 \mathrm{x}-3$, nilai $\mathrm{LD}_{50}$ diperoleh pada konsentrasi kolkisin sebesar $0.2 \%$. Meningkatnya persentase tunas pucuk yang mati disebabkan karena larutan kolkisin yang bersifat racun dapat merusak sel-sel tanaman. Menurut Suryo (2007), konsentrasi yang terlalu tinggi akan menyebabkan kematian pada tanaman. Kematian tunas pucuk ini terjadi beberapa hari setelah perlakuan kolkisin, tunas pucuk jeruk yang awalnya berwarna hijau, kemudian berubah perlahan menjadi warna coklat dan mati.

Perlakuan konsentrasi kolkisin memberikan pengaruh yang nyata terhadap pertambahan tinggi, jumlah daun, dan jumlah buku, tetapi tidak memberikan pengaruh yang nyata terhadap jumlah akar dan panjang akar tunas jeruk Siam

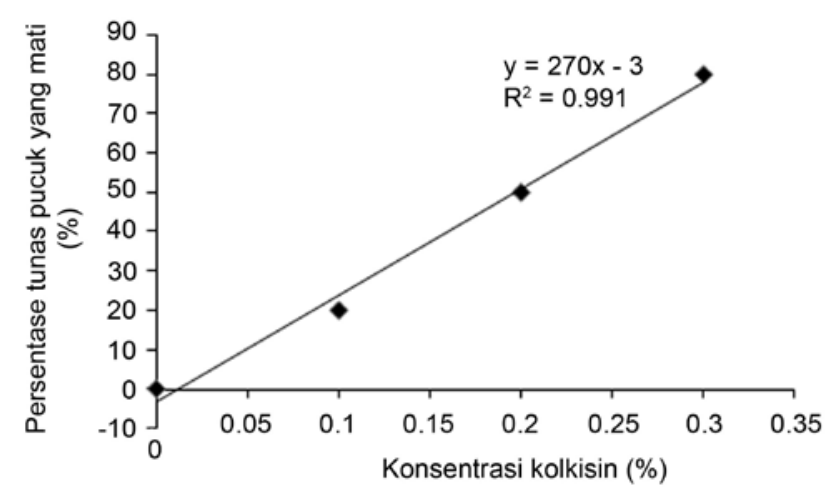

Gambar 1. Persentase tunas pucuk jeruk Siam Simadu yang mati setelah satu bulan perlakuan kolkisin

Simadu. Induksi tetraploid menggunakan kolkisin dapat menurunkan pertumbuhan tunas jeruk Siam Simadu (Tabel 2). Hal ini terlihat dari perlakuan kolkisin menghasilkan pertambahan tinggi, jumlah daun, jumlah buku, jumlah akar, dan panjang akar yang lebih rendah dibandingkan dengan tunas kontrol (kolkisin 0\%). Semakin tinggi konsentrasi kolkisin yang diberikan maka pertambahan tinggi, jumlah daun, jumlah buku, jumlah akar, dan panjang akar tunas juga semakin sedikit sehingga ukuran tanaman menjadi lebih kecil dibandingkan dengan tanaman kontrol (Gambar 2). Hasil yang diperoleh dari penelitian ini memiliki kesamaan dengan penelitian-penelitian sebelumnya yaitu pada beberapa tanaman rentan terhadap perlakuan kolkisin yang menyebabkan penurunan pertumbuhan pada tanaman Gossypium arboretum L (Rauf et al., 2006), Plantanus acerifolia (Liu et al., 2007), dragonhead (Omidbaigi et al., 2010b), dan Pelargonium x hortorum (Jadrna et al., 2010).

Terhambatnya pertumbuhan tunas diduga karena proses pembelahan sel yang abnormal akibat pengaruh kolkisin. Damayanti dan Mariska (2003) menyatakan bahwa pemberian kolkisin dapat mengakibatkan penundaan pertumbuhan akibat jaringan yang rusak dan memerlukan waktu lama untuk tumbuh. Menurut Suryo (2007) pembelahan sel menjadi lambat disebabkan jumlah kromosom yang mengganda.

Daun tunas pucuk yang diberi perlakuan kolkisin lebih tebal dibandingkan dengan daun tunas pucuk kontrol (Tabel 3). Semakin tinggi konsentrasi kolkisin, semakin tebal juga daun yang dihasilkan(Gambar 3). Hasil penelitian Omidbaigi

Tabel 2. Pengaruh konsentrasi kolkisin terhadap pertumbuhan tunas pucuk jeruk Siam Simadu pada umur 6 MSP

\begin{tabular}{lccccc}
\hline $\begin{array}{l}\text { Konsentrasi } \\
\text { kolkisin }(\%)\end{array}$ & $\begin{array}{c}\text { Pertambahan tinggi } \\
(\mathrm{cm})\end{array}$ & Jumlah daun & Jumlah buku & Jumlah akar & $\begin{array}{c}\text { Panjang akar } \\
(\mathrm{cm})\end{array}$ \\
\hline 0 & $1.43 \mathrm{a}$ & $5.80 \mathrm{a}$ & $4.80 \mathrm{a}$ & 0.3 & 0.32 \\
0.1 & $0.70 \mathrm{~b}$ & $2.00 \mathrm{~b}$ & $1.50 \mathrm{~b}$ & 0.2 & 0.09 \\
0.2 & $0.38 \mathrm{c}$ & $1.70 \mathrm{~b}$ & $1.30 \mathrm{~b}$ & 0.1 & 0.05 \\
0.3 & $0.24 \mathrm{c}$ & $0.40 \mathrm{c}$ & $0.20 \mathrm{c}$ & 0.0 & 0.00 \\
\hline
\end{tabular}

Keterangan: Angka yang diikuti huruf yang sama pada kolom yang sama menunjukkan hasil yang tidak berbeda nyata berdasarkan DMRT pada $\alpha=5 \%$ 


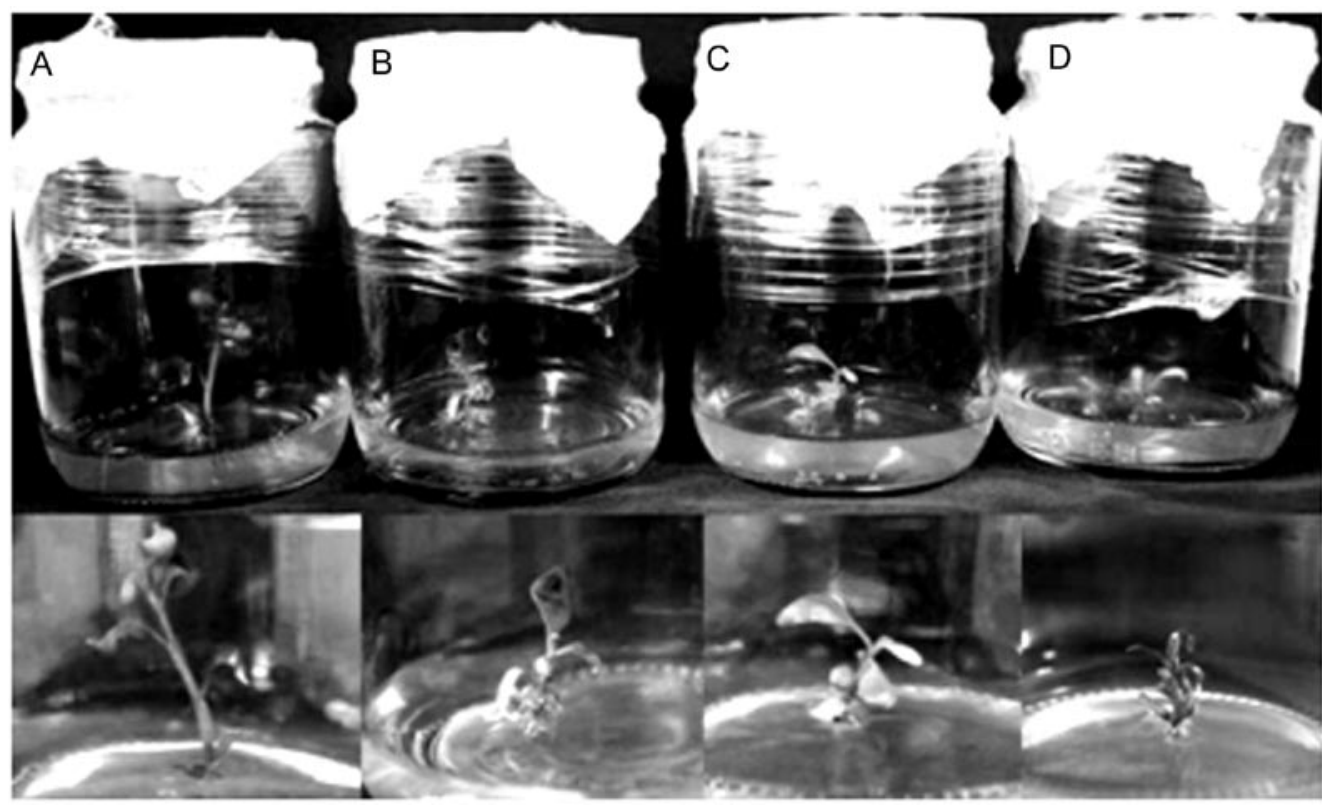

Gambar 2. Tunas jeruk Siam Simadu pada umur 6 minggu setelah perlakuan kolkisin: (A) $0 \%$; (B) $0.1 \%$; (C) $0.2 \%$; dan (D) $0.3 \%$

et al. (2010a) pada Ocimum basilicum L. menunjukkan bahwa tanaman tetraploid memiliki daun yang lebih tebal dibandingkan dengan tanaman diploid.

Identifikasi tingkat ploidi dapat dilakukan dengan analisis stomata. Teknik ini cepat, murah, tidak merusak, tidak memerlukan peralatan yang canggih, dan memiliki akurasi yang cukup tinggihingga 90\% (Cohen dan Yao, 1996). Menurut Rego et al. (2011), metode penghitungan jumlah kloroplas dalam sel penjaga adalah cara yang efektif dan cepat untuk menentukan tingkat ploidi. Jumlah kloroplas dalam sel penjaga dapat mengidentifikasi tanaman diploid dan tetraploid. Gu et al. (2005) dan Yu et al. (2009) juga telah meneliti tingkat ploidi berdasarkan jumlah kloroplas.

Tunas yang diberikan perlakuan kolkisin $0.1 \%$ memiliki jumlah kloroplas dua kali lebih banyak yaitu $18.25 \pm 1.71$ daripada jumlah kloroplas tunas kontrol (diploid) $8.67 \pm 0.58$ (Tabel 3), sehingga dapat diduga bahwa tunas yang diberikan perlakuan kolkisin $0.1 \%$ merupakan tunas tetraploid jeruk Siam Simadu. Penelitian Rego et al. (2011) pada tanaman Passiflora edulis Sims. memberikan hasil yang serupa, daun diploid dan tetraploid memiliki jumlah kloroplas masing-masing sebanyak 8.4 dan 16.3 per pasang sel penjaga sehingga daun tetraploid memiliki jumlah kloroplas dua kali lebih banyak dari daun diploid.

Lozykowska (2003) menyatakan bahwa ukuran panjang stomata berhubungan dengan jumlah kloroplas pada sel penjaga. Peningkatan jumlah kloroplas pada sel penjaga mengakibatkan ukuran stomata menjadi lebih besar (Gambar 4). Tunas perlakuan kolkisin 0.1\% memiliki stomata yang lebih besar daripada tunas kontrol karena tunas perlakuan kolkisin $0.1 \%$ memiliki jumlah kloroplas yang lebih banyak (Tabel 3). Hasil penelitian Tang et al. (2011), tanaman diploid memiliki ukuran stomata yang lebih kecil dibandingkan dengan tanaman tetraploid turunannya.

Ukuran stomata yang semakin besar mengakibatkan kerapatan stomata menjadi semakin rendah (Tabel 2). Tunas perlakuan kolkisin $0.1 \%$ memiliki kerapatan stomata yang lebih rendah daripada tunas control karena tunas perlakuan kolkisin $0.1 \%$ memiliki stomata yang lebih besar. Hasil yang sama juga diperoleh dari penelitian Rego et al. (2011) pada tanaman Passiflora edulis Sims., daun tetraploid memiliki kerapatan stomata yang lebih rendah dibandingkan dengan daun diploid.

Tabel 3. Pengaruh konsentrasi kolkisin terhadap tebal daun, kerapatan stomata, jumlah kloroplas per pasang sel penjaga, ukuran panjang dan lebar stomata jeruk Siam Simadu pada umur 6 MSP

\begin{tabular}{lccccc}
\hline $\begin{array}{l}\text { Konsentrasi } \\
\text { kolkisin }(\%)\end{array}$ & $\begin{array}{c}\text { Rata-rata tebal } \\
\text { daun }(\mu \mathrm{m})\end{array}$ & $\begin{array}{c}\text { Kerapatan stomata } \\
\left(\text { jumlah stomata } \mathrm{mm}^{-2}\right)\end{array}$ & $\begin{array}{c}\text { Jumlah kloropas/ } \\
\text { pasang sel penjaga }\end{array}$ & $\begin{array}{c}\text { Panjang stomata } \\
(\mu \mathrm{m})\end{array}$ & $\begin{array}{c}\text { Lebar stomata } \\
(\mu \mathrm{m})\end{array}$ \\
\hline 0 & $146.01 \pm 6.26$ & $67.52 \pm 7.64$ & $8.67 \pm 0.58$ & $18.32 \pm 1.24$ & $14.96 \pm 2.84$ \\
0.1 & $185.01 \pm 4.82$ & $59.87 \pm 8.70$ & $18.25 \pm 1.71$ & $23.66 \pm 2.63$ & $21.44 \pm 3.78$ \\
0.2 & $197.04 \pm 29.00$ & $54.35 \pm 15.57$ & $24.67 \pm 3.21$ & $22.34 \pm 0.85$ & $18.19 \pm 1.09$ \\
0.3 & $205.24 \pm 0.00$ & $47.56 \pm 51.55$ & $32.00 \pm 1.41$ & $19.59 \pm 2.52$ & $17.31 \pm 1.09$ \\
\hline
\end{tabular}

Keterangan: Rata-rata \pm SD 


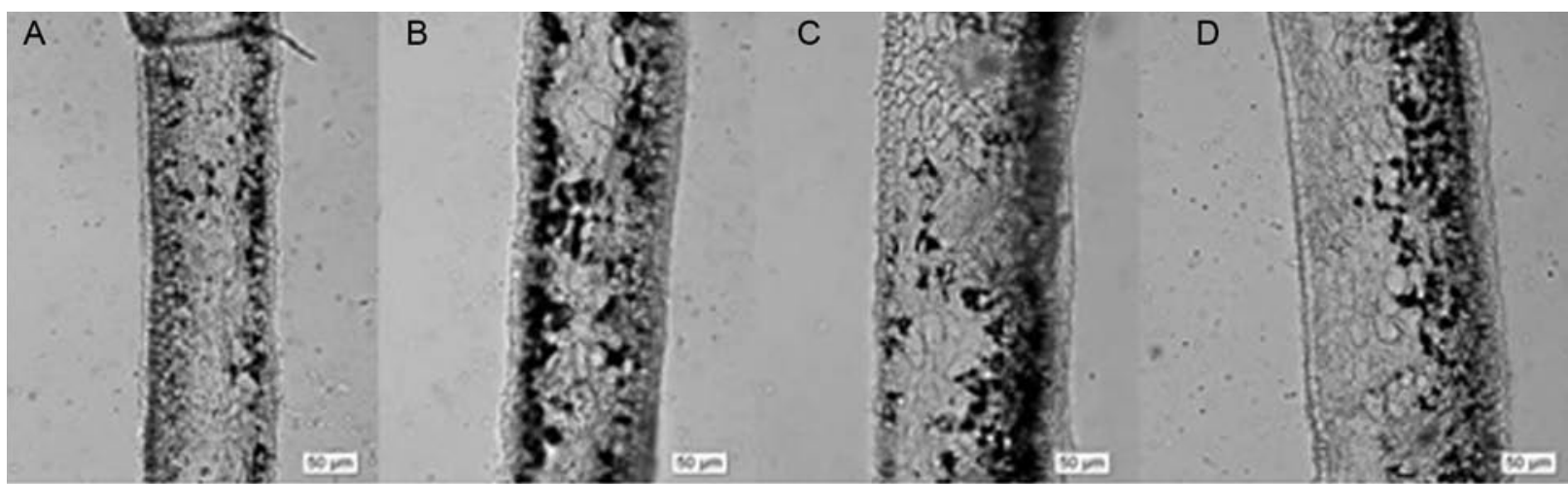

Gambar 3. Tebal daun tunas pucuk jeruk Siam Simadu pada umur 6 MSP kolkisin: (A) 0\%; (B) 0.1\%; (C) 0.2\%; dan (D) $0.3 \%$

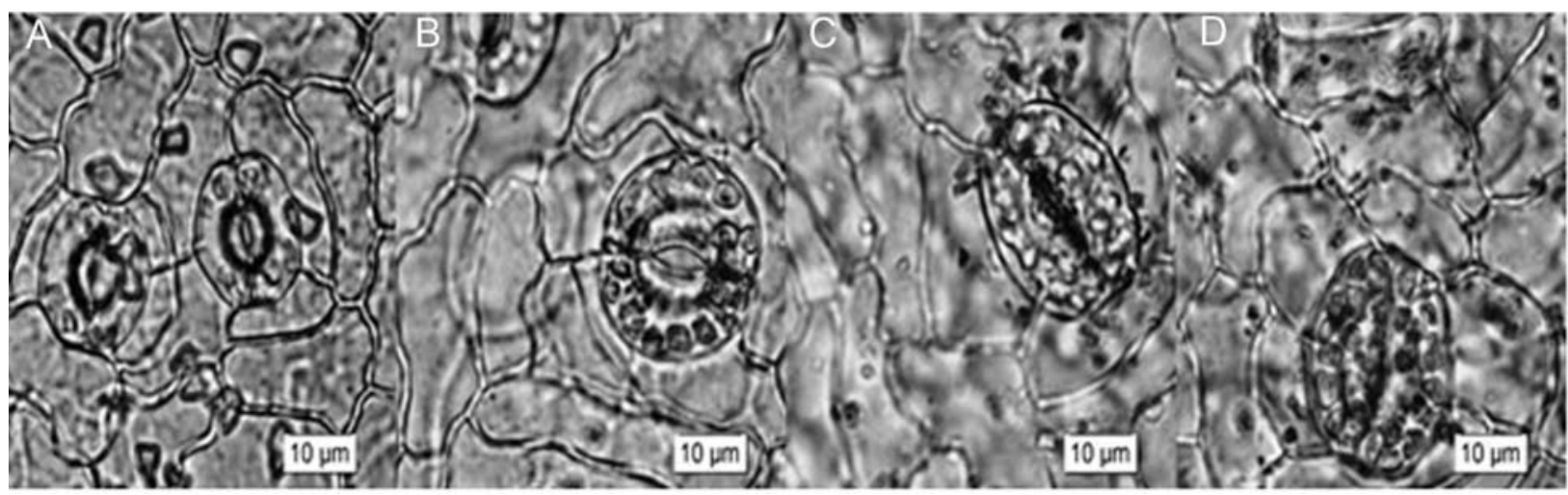

Gambar 4. Ukuran dan jumlah kloroplas pada sel penjaga daun jeruk Siam Simadu pada umur 6 MSP kolkisin: (A) $0 \%$; (B) $0.1 \%$; (C) $0.2 \%$; dan (D) $0.3 \%$ dengan pembesaran $1000 \mathrm{x}$

\section{KESIMPULAN}

Nilai $\mathrm{LD}_{50}$ diperoleh pada konsentrasi kolkisin sebesar $0.2 \%$. Induksi tetraploid menggunakan kolkisin dapat menurunkan pertumbuhan tunas jeruk Siam Simadu, tunas yang diberi perlakuan kolkisin menghasilkan pertambahan tinggi, jumlah daun, jumlah buku, jumlah akar, dan panjang akar yang lebih rendah dibandingkan dengan tunas kontrol (kolkisin 0\%). Daun tunas pucuk yang diberikan perlakuan kolkisin lebih tebal dibandingkan dengan daun tunas pucuk kontrol. Tunas yang diberikan perlakuan kolkisin $0.1 \%$ memiliki jumlah kloroplas dua kali lebih banyak daripada jumlah kloroplas tunas kontrol, ukuran stomata yang lebih besar dan kerapatan stomata yang lebih rendah dibandingkan dengan tunas kontrol.

\section{DAFTAR PUSTAKA}

Aisyah, S.I., H. Aswidinnoor, A. Saefuddin, B. Marwoto, S. Sastrosumarjo. 2009. Induksi mutasi pada stek pucuk anyelir (Dianthus caryophyllus Linn.) melalui iradiasi sinar gamma. J. Agron. Indonesia 37:62-70.

Aleza, P., J. Jua'rez, P. Ollitrault, L. Navarro. 2009. Production of tetraploid plants of non apomictic citrus genotypes. Plant Cell Rep. 28:1837-1846.
Ascough, G.D., J. van Staden, J.E. Erwin. 2008. Effectiveness of colchicine andoryzalin at inducing polyploidy in Watsonia lepida N.E. Brown. HortSci. 43:22482251.

Cohen, D., J.L. Yao. 1996. In vitro chromosome doubling of nine Zantedeschia cutivars. Plant Cell Tiss. Organ Cult. 47:43-49.

Damayanti, F., I. Mariska. 2003. Induksi poliploidi pada hibrid F1 hasil persilangan antar spesies pada tanaman panili secara in vitro. J. Ilmiah Mulawarman Scientifie 2:12-17.

Direktorat Jenderal Hortikultura. 2013. Nilai impor dan ekspor buah tahun 2012. http://www.hortikultura. deptan.go.id [3 September 2013].

Dhooghe, E., K. Van Laere, T. Eeckhaut, L. Leus, J. Van Huylenbroeck. 2011. Mitotic chromosome doubling of plant tissues in vitro. Plant Cell Tiss. Organ Cult. 104:359-373.

Gmitter, J.R., X. Ling. 1991. Embryogenesis in vitro and nonchimeric tetraploid plant recovery from undeveloped Citrus ovules treated with colchicines. J. Amer. Soc. Hort. Sci. 116:317-321. 
Gu, X.F., A.F. Yang, H. Meng, J.R. Zhang. 2005. In vitro induction of tetraploid plants from diploid Zizyphus jujuba Mill cv. Zhanhua. Plant Cell Rep. 24:671676.

Husni, A., A. Purwito, I. Mariska, Sudarsono. 2010. Regenerasi jeruk Siam melalui embriogenesis somatik. J. AgroBiogen 6:75-83.

Jadrna, P., O. Plavcova, F. Kobza. 2010. Morphological changes in colchicine-treated Pelargonium $\mathrm{x}$ hortorum L.H. Bailey greenhouse plants. HortScience 37:27-33.

Liu, G., Z. Li, M. Bao. 2007. Colchicine-induced chromosome doubling in Plantanus acefolia and its effect on plant morphology. Euphytica 157:145-154.

Lozykowska, K.S. 2003. Determination of the ploidy level in chamomile (Chamomilla recutita (L.)Rausch.) strains rich in $\alpha$-bisabol. J. Appl. Genet. 44:151-155.

Omidbaigi, R., M. Mirzaee, M.E. Hassani, M.S. Moghadam. 2010a. Induction and identification of polyploidy in basil (Ocimum basilicum L.) medicinal plant by colchicine treatment. Intl. J. Agron. Plant Prod. 4:8798.

Omidbaigi, R., S. Yavari, M.E. Hassani, S. Yavari. 2010 b. Induction of autotetraploidy in dragonhead (Dracocephalum moldavica L.) by colchicine treatment. J. Fruit Ornam. Plant Res. 18:23-35.

Rauf, S., I.A. Khan, F.A. Khan. 2006. Colchicine-induced tetraploidy and changes in allele freguencies in colchicine-treated populations of diploid assessed with RAPD markers in Gossypium arboretum L. Turk. J. Biol. 30:93-100.
Rego, M.M., E.R. Rego, C.H. Bruckner, F.L. Finger, W.C. Otoni. 2011. In vitro induction of autotetraploids from diploid yellow passionfruit mediated by colchicine and oryzalin. Plant Cell Tiss. Organ Cult. 107:451459.

Suryo, H. 2007. Sitogenetika. Gajah Mada University Press. Yogyakarta.

Takahira, J., A. Cousin, M.N. Nelson, W.A. Cowling. 2011. Improvement in efficiency of microspore culture to produce doubled haploid canola (Brassica napus L.) by flow cytometry. Plant Cell Tiss. Organ Cult. 104:51-59.

Tang, Z.Q., D.L. Chen, Z.J. Song, Y.C. He, D.T. Cai. 2011. In vitro induction and identification of tetraploid plants of Paulownia tomentosa. Plant Cell Tiss. Organ Cult. 102:213-220.

Morel, G., R.H. Wetmore. 1951. Fern callus tissue culture. Am. J. Bot. 38:141-143.

Wu, Jin-Hu, P. Mooney. 2002. Autotetraploid tangor plant regeneration from in vitro Citrus somatic embryogenic callus treated with colchicines. Plant Cell Tiss. Organ Cult. 70:99-104.

Yu, Z., Z. Haage, V.E. Streit, A. Gierl, R.A.T. Ruiz. 2009. A large number of tetraploid Arabidopsis thaliana lines, generated by a rapid strategy, reveal high stability of neo-tetraploids during consecutive generations. Theor. Appl. Genet. 118:1107-1119.

Zeng, S.H., C.W. Chen, L. Hong, J.H. Liu, X.X. Deng. 2006. In vitro induction, regeneration and analysis of autotetraploids derived from protoplasts and callus treated with colchicine in Citrus. Plant Cell Tiss. Organ Cult. 87:85-93. 